\title{
SOCIAL CONTINUITY AND FORCED Change: The NoOngar CASE; BENNELL V STATE OF WESTERN AUSTRALIA
}

\author{
SAMANTHA HePBuRN* \\ '...being a Noongar involves three ingredients: being \\ born to a Noongar father or mother; living in Noongar \\ country; and having learned Noongar ways. ${ }^{1}$
}

\section{INTRODUCTION}

The recent single judgement by Wilcox $\mathrm{J}$ in the Federal Court in Bennell $v$ State of Western Australia (hereinafter referred to as Bennell) reveals an important shift in the trajectory of native title jurisprudence. The conclusion by Wilcox J, that the Noongar Aboriginal community held native title rights over the claimed area, was the product of a broader, more flexible approach to the test espoused by the High Court in Members of the Yorta Yorta Aboriginal Community $v$ Victoria (hereinafter referred to as Yorta.) ${ }^{2}$ This case note briefly examines the implications of this important decision for future native title claims.

\section{BACKGROUND TO THE CASE}

In Members of the Yorta Yorta Aboriginal Community $v$ Victoria a majority of the High Court rejected the native title claim by the Yorta Yorta community, holding that the claimed area, a large tract of land and water in Northern Victoria and Southern New South Wales, did not satisfy the native title requirements. The trial judge, Olney J, held that on the facts, the Yorta Yorta people had lost their traditional connection with the land. In particular, Olney $\mathrm{J}$ concluded that the most significant evidence came from that of an English pastoralist, Edward Curr, who wrote in the 1840s. Olney J concluded that the

\footnotetext{
* Senior Lecturer, School of Law, Deakin University.

${ }^{1}$ Bennell v State of Western Australia [2006] FCA 1243 at [770] - comments made by $\mathrm{Mr}$ Bropho, a senior elder in the Noongar community.

2 [2002] 194 ALR 538.
} 
writings of Curr revealed evidence of traditional practices which hadsubsequently been abandoned. By abandoning their traditional lifestyle, Olney J concluded that the Yorta Yorta people had severed their traditional connection and therefore, could not satisfy the native title requirements as set out under s223(1) of the Native Title Act 1993 (Cth). A majority of the Full Court, Branson and Katz JJ, rejected the appeal, concluding that the finding of fact that Olney $\mathrm{J}$ had made was open to him and that he had not erred in law. ${ }^{3}$

The High Court also rejected the appeal, concluding that on the facts, the Yorta Yorta community had not proven that their laws and customs were connected to a pre-sovereignty normative society and therefore had not satisfied the statutory concept of 'traditional'. The majority concluded that the statutory definition of native title, in particular the use of the words 'traditional laws acknowledged, and the traditional customs observed' meant that native title could only be established where the rights and interests of indigenous claimants were connected with the claimed land and sourced in a pre-sovereignty, normative indigenous system. Where that normative system has continued to the present day, without interruption or cessation, the laws and customs of the society will satisfy the statutory requirements. If the society has been dispersed, dislocated or interrupted as a consequence of European settlement, the laws and customs will not satisfy the statutory requirements because they will 'cease to have continued existence and vitality'.4

This decision was described as having the effect of preserving indigenous laws and customs in a 'kind of colonial formaldehyde since 1788', subjecting Australia's indigenous people to a 'neo-colonialist tradition' and ignoring the continuing evolution and complexity of indigenous traditions. ${ }^{5}$ It formed the legal backdrop for the Bennell decision.

\footnotetext{
${ }^{3}$ [1998] FCA 1606. For a full discussion of the Full Court Appeal see J Cockayne, 'Members of the Yorta Yorta Aboriginal Community v Victoria: Indigenous and Colonial Traditions in Native Title’ (2001)25 Melbourne University Law Review 786. ${ }^{4}$ [2002] 194 ALR 538 at [52].

${ }^{5} \mathrm{~K}$ Anker, 'Law in the Present Tense: Tradition and Cultural Continuity in Members of the Yorta Yorta Aboriginal Community v Victoria' (2004) 28 Melbourne University Law Review 1, 14; J Cockayne, 'Members of the Yorta Yorta Aboriginal Community v Victoria: Indigenous and Colonial Traditions in Native Title’ above n 2, 807.
} 


\section{THE BENNELL DECISION}

The judgement of Wilcox $\mathrm{J}$ in Bennell $v$ State of Western Australia was handed down on 19 September 2006. After assessing voluminous evidence from thirty aboriginal witnesses, and five expert witnesses - including two historians, two anthropologists and a linguistic expert - his Honour concluded that the Noongar Aboriginal community had satisfied the statutory test for proving native title. The decision was a controversial one, described as 'sparking fresh hope' for native title jurisprudence. ${ }^{6}$ The claimed area covered approximately 193,000 square kilometres and included the whole of the Perth metropolitan area and large regional centres such as Bunbury, Busselton, Margaret River, Alban, York, Toodyay, Katanning, Merredin and many other towns.

In considering the evidence, Wilcox $\mathrm{J}$ concluded that there were two primary issues to determine. First, the identity of the community whose laws and customs governed the use and occupation of the land within the claim area in 1829 and second, whether this community continues to exist, acknowledge and observe those laws and customs, albeit perhaps in an attenuated or somewhat changed form. ${ }^{7}$

With respect to the first test, Wilcox $\mathrm{J}$ concluded that on the facts it was clear, despite the dislocation of community members, that there was a single Aboriginal community throughout the whole of the south-west of Western Australia known as the Noongar community.

This conclusion was based upon a broad ranging assessment of different indigenous and non-indigenous evidence and included a 'wealth' of materials left by early European writers as well as expert evidence and indigenous statements. Of particular cogency for Wilcox J was the evidence given by $\mathrm{Dr}$ Nicholas Thieberger, an expert in Aboriginal languages, setting out that in 1829 a single language was used throughout the entire claimed area with minor dialectic differences. This evidence, combined with clear proof of unified customary practices within the claimed area and interaction between people living within the claimed area provided a positive indication of social unity. His Honour concluded that '[t]he current normative system is that of the Noongar society that existed in 1829 , and which continues to be a body

\footnotetext{
${ }^{6}$ See S Brennan, 'Native Title is Still Alive’ The Age (Melbourne), 25 September, 2006.

${ }^{7}$ Taken from the statement of Wilcox J preceding the judgement: Bennell $v$ State of Western Australia [2006] FCA 1243.
} 
united, amongst other ways, by its acknowledgement and observance of some of its traditional laws and customs. ${ }^{8}$

With respect to the second test, Wilcox $\mathrm{J}$ concluded that the Noongar community had not been abandoned and did continue to exist to the present day. Thus, it satisfied the statutory requirement, highlighted in Yorta, that the claimants show a connection to a pre-sovereignty normative system.

Significantly, Wilcox $\mathrm{J}$ held that whilst the traditional laws and customs practised by the pre-sovereignty Noongar community normative system had changed dramatically over time, those changes did not rupture the traditional connection. Rather, they constituted a 'recognisable adaptation' to the vicissitudes of European settlement. For example, Wilcox J concluded that the boodjas (home areas) that characterised the pre-sovereignty Noongar community had effectively disappeared and that whilst this change was significant, it was 'readily understandable'. It was 'forced upon the Aboriginal people by white settlement. As white settlers took over, and fenced, the land, Aborigines were forced off their home areas; the 'bands' or 'tribes', comprising several related families, were broken up.....The ability to maintain the 'home area' element of the pre-settlement normative system was lost.'

\section{CONTINUITY OF SOCIETY VS UNCHANGED LAWS AND CUSTOMS}

The real point of departure for the Bennell decision lay in its conclusions concerning the impact of 'changed' laws and customs. Wilcox J made it clear that he was not going to adopt a 'frozen in time' attitude to the laws and customs of the Noongar community. He acknowledged several times that continuity of the pre-settlement society depended upon their ability to change and adapt to the different conditions imposed upon them. A number of related issues flowed from these conclusions.

First, it clear that Wilcox $\mathrm{J}$ was prepared to endorse necessary, adaptive changes to traditional laws and customs necessary for post-settlement, community survival. He expressly stated that for 'the normative system to have survived, it was obviously necessary to allow a degree of choice of country exceeding what would have been necessary in more ordered, presettlement times. ${ }^{10}$ Indigenous communities had to modify their traditional laws and customs to accommodate and survive the impact of European

\footnotetext{
${ }^{8}$ Bennell v State of Western Australia [2006] FCA 1243 [791].

${ }^{9}$ Bennell v State of Western Australia [2006] FCA 1243 [785].

${ }^{10}$ Bennell v State of Western Australia [2006] FCA 1243 [775].
} 
settlement and these changes should not strip indigenous communities of their traditional connection. The focus, according to Wilcox J, should not be upon unchanged laws and customs but rather, 'evidence of the continuity of the society."11 Wilcox J quotes from the Yorta decision to support this conclusion. Specifically, his Honour revisited the comments of the majority in Yorta:

[I]t is necessary to demonstrate that [despite the changes] the normative system out of which the claimed rights and interests arise is the normative system of the society [at sovereignty]...not a normative system rooted in some other, different, society...it must be shown that the society...has continued to exist throughout that period as a body united by its acknowledgement and observance of the laws and customs. ${ }^{12}$

Wilcox J interpreted these comments as proof of the fact that continuity with a pre-sovereignty normative community will only be affected by fundamental social change, not merely legal or customary adaptations. This is an interesting conclusion because the comments themselves emanate from a larger section of the majority judgement in Yorta in which it is stated that traditional laws and customs need to continue substantially uninterrupted. The majority in Yorta allude to the fact that changes wrought by European settlement may make it 'very difficult' to establish a traditional connection. However, the majority were only prepared to qualify the continuity requirement by endorsing laws and customs which had continued 'substantially uninterrupted'. By contrast, Wilcox J in Bennell was prepared to accept complete interruption provided the interruption was a consequence of imposed change, producing necessary and recognisable adaptation.

This pragmatic conclusion takes a fairer, more balanced approach to native title examination than the 'tide of history' approach endorsed by Yorta. It acknowledges the inevitability of social, legal and cultural adjustment following European settlement. ${ }^{13}$ Further, it raises the possibility of future cases examining social change in terms of whether it was forced or natural rather than simply examining it in terms of degree. Wilcox $\mathrm{J}$ specifically

${ }^{11}$ Bennell v State of Western Australia [2006] FCA 1243 [776].

${ }^{12}$ Members of the Yorta Yorta Aboriginal Community v Victoria (2002) 194 CLR 538 [89] quoted by Wilcox J in Bennell v State of Western Australia [2006] FCA 1243 [776].

${ }^{13}$ A reference to the words of Brennan J in Mabo v State of Queensland [No 2](1992)175 CLR 1 at 43: 'when the tide of history has washed away any real acknowledgment of traditional law and any real observance of traditional customs, the foundation of native title has disappeared.' 
states that in determining whether a change indicates a lack of social continuity, an examination of all of the relevant circumstances should be undertaken including 'the importance of the relevant laws and customs and whether the changes seem to be the outcome of factors forced upon the community from outside its ranks. ${ }^{14}$ Where the element of 'force' or 'control' underlies the change, the necessary adaptation should not be treated as a cessation of traditional connection, even if it has interrupted continuity with laws and customs exercised by pre-sovereignty normative communities, because the change itself was mandated by external circumstances. This shift in focus would enable native title requirements to be satisfied notwithstanding the fact that the community has experienced dramatic social and cultural upheaval,

\section{CONCLUSION}

The decision of Wilcox $\mathrm{J}$ in Bennell represents an important shift in the development of native title jurisprudence. The flexibility and breadth of focus that Wilcox J displayed, both in his assessment of the facts and his interpretation of the law, imbues the decision with a sense of colonial perspective. His ultimate acceptance, as set out in his preceding statement, of the 'devastating effect on the Noongars of the dispossession from their land and other social changes' and his preparedness to endorse the validity of social continuity in the face of such change may, subject to impending appeals, mark the onset of a 'post-colonial' mindset. ${ }^{15}$

\footnotetext{
${ }^{14}$ Bennell v State of Western Australia [2006] FCA 1243 [776].

${ }^{15}$ Bennell v State of Western Australia [2006] FCA 1243, preceding statement at 2. For a discussion on 'post-colonial' identity see: G Christie, 'A Colonial Reading of Recent Jurisprudence: Sparrow, Dalgamuukw and Haida Nation' (2005) Windsor YearBook Acess Just 17 esp 32-35.
} 